\title{
Understanding the Processual and Contextual Aspects of Science by Means of the History of Photosynthesis
}

\author{
Arzu Saka * \\ Trabzon University, TURKEY
}

Received: March 5, 2019 - Revised: March 28, $2019 \cdot$ Accepted: April 5, 2019

\begin{abstract}
The aim of this study is to present pre-service biology teachers with reading texts about the research of Van Helmont and Joseph Priestley relate to the subject of photosynthesis, for their familiarization with the processual and contextual aspects of science and their understanding of the nature of science, and to reveal the extent to which these texts contribute to the teacher candidates. The study was carried out by "action research method". The sample consisted of 66 biology pre-service teachers studying at Karadeniz Technical University between the years of 2016 to 2018. In this study, two separate reading texts were prepared in order to increase pre-service teachers' processual and contextual understanding, and after the teacher candidates had read the texts, they were asked to answer the related questions. Percentage and frequency values were determined by grouping the answers as "correct, partially correct, incorrect and unanswered". The fact that in this study, only $47 \%$ of the pre-service teachers were able to form a correct hypothesis means that their skills in this regard are in need of development. Candidates experienced some difficulty in interpreting statements that were not given explicitly in the text. The candidates' level of critical thinking is at a good level. It has been determined that they have post-modern view as epistemological belief. There is a need for designing instructional materials covering conceptual, processual, contextual dimensions of science in different subjects at university level and presenting them to biology teachers in book format.
\end{abstract}

Keywords: History of Science, photosynthesis, aspects of science.

To cite this article: Saka, A. (2019). Understanding the processual and contextual aspects of science by means of the history of photosynthesis. European Journal of Educational Research, 8(2), 633-646. doi: 10.12973/eu-jer.8.2.633

\section{Introduction}

We could not talk about life on earth without sun. Photosynthesis is the only mechanism that synthesis organic matter using this light energy of the sun (Raven, Johnson, Mason, Losos \& Singer, 2011). Considering the effects of global climate change and the presence of people who are still suffering from famine and hunger in the global world, the importance of carbon dioxide capture in the atmosphere becomes even more important. It can be said that photosynthesis is the best sustainable process in nature (Janssen et al., 2014). Furthermore, thanks to photosynthesis, the existence of a large part of the existing energy resources on our planet, such as fossil fuels and biomass, is ensured and research into obtaining clean fuel by means of microalgae is continuing (Ahopelto, Mikkila-Erdmann, Anto \& Penttinen, 2011; Hall \& Rao, 1994; Marques da Silva, Bernardes da Silva \& Padua, 2007; Matthews, 2009; Melis \& Happe, 2004). Global demand for food depends to a large extent on photosynthetic productivity, since photosynthesis feeds almost all living creatures either directly or indirectly (Campbell et al., 2010). Nowadays, the crop yields obtained are far from meeting the projected needs of the estimated increased population, a situation which threatens global food security (Janssen et al., 2014).

Students who learned the photosynthesis subject well will also better understand other issues such as environmental issues, the state of the atmosphere, greenhouse gases, climate changes, carbon footprints, protection of forests and nutritional problems. Therefore, it must be taught effectively at all educational levels (Matthews, 2009; Metioui, Matoussi \& Trudel, 2016; Vartak, 2006). However, it can be said that photosynthesis is a key concept for individuals to be a conscious citizen for a sustainable environment (Matthews, 2009). Photosynthesis is one of the main subjects in biology and constitutes a basis for achieving cognitive organisation and for learning many subjects in a meaningful way (Mikkila-Erdmann, 2001; Yenilmez \& Tekkaya, 2006). Some previous studies showed that there are misconceptions about photosynthesis in students at different levels. (Bahar, 2003; Crane \& Winterbottom, 2008; Kose \& Usak, 2006;

\footnotetext{
* Correspondence:

Arzu Saka, Trabzon University, Fatih Faculty of Education, Turkey

$\bowtie$ arzus123@gmail.com
} 
Kose, 2008; Ozay \& Oztas, 2003; Ross, Tronson \& Ritchie, 2006; Svandova, 2014; Tekkaya, Capa \& Yilmaz, 2000; Yenilmez \& Tekkaya, 2006). A common misconception related to photosynthesis is that just like animals, plants are also believed to obtain their nutrition in ready form straight from the soil. In this case, it appears that the ontological difference between plants and animals is not understood. Students have difficulty in understanding that photosynthesis is the operation of a matter cycle and describe this process as merely an exchange of gases. It is reported that students believe that plants do not respire, and that they perceive respiration and photosynthesis as two reactions that are opposite to each other. In understanding photosynthesis, respiration and decomposition and the relationships between these in the ecosystem, students experience difficulties in explaining the matter cycle in nature (Gonzalez-Rodriguez, Garcia-Barros \& Martinez-Lozada, 2009). To be able to make students understand the fact that plants use carbon dioxide and release oxygen during the operation of absorbing solar energy and converting it into chemical energy, and that due to this, other creatures are able to maintain their lives, the information needs to be organised (Ahopelto, Mikkila-Erdmann, Anto \& Penttinen, 2011; Gonzalez-Rodriguez, Garcia-Barros \& Martinez-Lozada, 2009).

In many countries, educating students to be scientifically literate individuals is revealed as a priority target in teaching programmes (Dogan \& Yilmaz, 2013; Keskin, Tezel \& Acat, 2016). Koch and Eckstein (1995) define scientific literacy as the skill of comprehending a scientific text with an active and critical involvement. An individual who is scientifically literate is able to examine a text with a critical approach and interpret that text from a theoretical perspective (TuncSahin \& Say, 2010). The most important quality of a scientifically literate individual is also regarded to be possession of a sufficient understanding of the nature of science (Driver, Leach, Millar \& Scott, 1996; McComas, Clough \& Almazroa, 2002). According to Tasar (2003), "the nature of science includes understanding what science is, and what role it plays; who scientists are, and what role(s) they play; the nature of scientific evidence, observations, facts, rules, laws, and the scientific method; and how science is done". It is emphasised that the use of a history-based approach during the teaching of science subjects is an important tool in understanding the nature of science and in implementing a constructivist approach (Cakici, 2009; Henke \& Hottecke, 2015; Matthews, 1994; Morgil, Temel, Gungor-Seyhan \& UralAlsan, 2009). In its briefest definition, the concept of history of science is defined as the birth of science and the story of its development. Individuals who are informed about the historical developments in science can make very important gains in understanding how scientists define a problem, how they form a hypothesis, what they need to observe when conducting a study, what their methods of data collection are, how they reach a conclusion in the study, how these conclusions or hypotheses will change, how important it is for the research findings to be reported and published, and the effects of the dogmas and imaginations possessed by scientists on their research. Moreover, they can perceive how important it is that before the studies made by these scientists, studies had been made by other people conducting research into the subject, how important it is to be patient, and the fact that science is cumulative. Thanks to the truelife, concrete examples that they encounter, their skills in investigative research, critical thinking and problem solving will develop (Henke \& Hottecke, 2015). In contrast to traditional approaches, a history-focused approach to teaching can teach students that always being focused on success is not a correct approach since scientists can sometimes find incorrect results, and these findings may also be a source of inspiration for other scientists (Metioui, Matoussi \& Trudel, 2016). Considered in this context, it can be said that the history of science is an important tool in educating students as scientifically literate individuals (Lacin-Simsek, 2009). Individuals who are scientifically literate will not look at scientific studies from a distance; rather, due to the good relationships they have formed, they will begin to consider science as something that they themselves can perform and easily understand (Appelget, Matthews, Hildreth \& Daniel, 2002). For example, students' analysis of the research conducted in the 1770s is essential for their understanding of how Joseph Priestley interpreted the results of his experiment, in which he stated that plants clean the air due to a gas that emerges via a process opposite to the reactions occurring when breathing in and out, even though in those years oxygen had not yet been discovered, and their understanding of the limitations of the age in which he lived (Metioui, Matoussi \& Trudel, 2016; Matthews, 2009).

According to Klopfer (1969), the history of science must explain the conceptual, processual and contextual aspects of science. In order to increase conceptual understanding by using the history of science, the presentation of scientific knowledge can be focused on the enriched or variable nature. To increase processual understanding, students can be taught to gain an understanding of the scientific process. In other words, an understanding of the processes of thinking, investigating, analysing, deciding, inferring, reporting and implementing will be facilitated. To ensure contextual understanding, an understanding of the psychological, social and cultural aspects of involvement in science can be facilitated. Examining course books, it is seen that from the viewpoint of history of science, the narrative content is related to the conceptual aspect of science, and that the processual or contextual aspects are not dealt with or are inadequately discussed (Lacin-Simsek, 2009; Henke \& Hottecke, 2015). In a general sense, it is known that a scientist's name and nationality, and if known, his history and his contribution to the subject are included (Schattner, 2015). It can be said that when considered from the contextual perspective of science, narratives such as these contribute to the cultural aspect. However, it is considered that teaching narratives need to be of a quality and depth to be able to draw students' attention (Wang, 1998). In order to develop an understanding regarding the processual and contextual aspects of science, it is thought that books should explain to us not only what we know, but also how this knowledge was obtained (Gallagher, 1991). Since our primary school years, we have all been familiar with the story of the apple that fell on Newton's head while he was sitting under a tree and his discovery of the law of gravity. It is unfortunate that 
what we remember from this story should not be the fact that scientists can suddenly make a very important discovery (Matthews, 1994) since this is neither correct information nor a correct approach to teaching the concept of scientific process. Students must be informed that in order for Newton to extract a law from this momentary observation, he worked on the subject for a very long time, he examined the work of scientists that had come before him, and he made countless observations. Yet, it may be possible to develop an understanding of scientific method by referring to the processual and contextual aspects of science. It is seen that this situation is neglected in biology books. In the study conducted by Narguizian (2002), it was determined that there were similar problems in seven separate books examined, that history of science was generally utilised in the conceptual field, that it was utilised very little in the processual field, and that it was not used at all in the contextual field.

It is emphasised that another difficulty encountered in utilising the history of science in science teaching may be teaching programmes (Metioui, Matoussi \& Trudel, 2016). In the biology curriculum currently used in Turkey, on the subject of photosynthesis, the statement "examples of scientists who have contributed to the understanding of the photosynthesis process are to be given by briefly mentioning their studies" is included (MEB, 2018). It is not possible to present every subject with a history-oriented approach in course books. However, it is stated that subjects such as evolution (Jensen \& Finley, 1995) and photosynthesis (Wandersee, 1985) are suitable for teaching with this approach.

When the researches on photosynthesis were examined between 1990 and 2014, it was understood that it was almost entirely on the conceptual dimension. (Patrick \& Matteson, 2018). Therefore, the research question of this study is; while pre-service biology teachers are learning the subject of photosynthesis, what kind of gains can they make by encountering its processual and contextual aspects?

\section{Methodology}

\section{Research Goal}

The aim of this study is to present pre-service biology teachers with reading texts about the research of Van Helmont and Joseph Priestley relate to the subject of photosynthesis, for their familiarisation with the processual and contextual aspects of science and their understanding of the nature of science, and to reveal the extent to which these texts contribute to the teacher candidates.

\section{Research Method}

The study was carried out by "action research method". Cohen, Manion and Morrison (2007) defined action research "as in methods developed for solving the problem in practice at a particular time in the education process". In action research studies, the problems encountered in education are determined in a scientific way, and the solution is tried to be produced (Ekiz, 2013). The most distinctive feature of this method is that researchers are involved in the research process to change and improve their actions. For the aim of this study, since it is to test or evaluate an application within a predetermined theoretical framework, a type of technical/scientific action research has been used. Collins and Spiegel (2001) defined a systematic method, action research, as a four-stage cycle: 1. Description the problem, 2. Planning, 3. Implementing the plan, 4. Evaluating the impact of implementation. In this research, the steps in the cycle are designed as follows:

1. Description the Problem. The researcher teaches the "Scientific Research Methods, Nature of Science and History of Science" classes. The researcher observed that there are serious deficiencies in teacher candidates in some of the concepts and achievements included in the courses.

2. Planning. This study was organized in order to identify these shortcomings and to gain some skills. The researcher planned to work with the pre-service biology teacher. The aim of the course is to develop the skills that are deemed incomplete by the students with two separate reading texts.

3. Implementing the Plan. They were asked to apply these reading texts in the course hour, to answer the questions at the end of the texts and to fill in the relevant sections. Details are described in data collection tools and implementation.

4. Evaluating the Impact of Implementation. The data obtained in two weeks were analysed by the researcher. Details are explained in the section analysis of data.

\section{Sample}

The sample consisted of 66 biology pre-service teachers studying at Karadeniz Technical University between the years of 2016-2018. In Turkey, biology teachers are trained in education departments of higher education for 4 years. After this undergraduate programme pre-service teachers must take national exam and are appointed as teachers in the public schools. The pre-service biology teachers included in the study are in the third and fourth year of a 4-year undergraduate programme in education faculty.

\section{Data Collection Tools and Implementation}

In a previous study conducted by the researcher, a worksheet on the subject of photosynthesis was developed and applied in order to contribute to pre-service teachers' conceptual understanding (Saka, 2019). In this study, two 
separate reading texts were prepared in order to increase pre-service teachers' processual and contextual understanding, and after the teacher candidates had read the texts, they were asked to answer the related questions. The reading text aimed at developing processual understanding is shown in Appendix 1 while the reading text aimed at increasing contextual understanding is shown in Appendix 2. In the related literature, it is emphasised that in order to increase processual understanding, students can be taught to gain an understanding of the scientific process, and that this can be achieved by facilitating understanding of the processes of thinking, investigating, analysing, deciding, inferring, reporting and implementing (Lacin Simsek, 2009). Therefore, in the reading text that was prepared with the title "Van Helmont", at the first stage, how the scientist planned his first studies, and what he knew or did not know while deciding on the implementation process and reaching a conclusion, at a time when the mechanism of photosynthesis was not yet known, were explained. At the second stage, based on the text they had read in the first part, the pre-service teachers were asked four open-ended questions inquiring about what sort of hypothesis the scientist might have formed before beginning his experiment, how long his studies lasted, what kind of observations and implementations he made, and how we should evaluate these applications today. Thereby, the aim was for the candidates to develop their ability to understand both what they had read and the processual aspect of science.

In order to ensure contextual understanding, it is stressed that understanding of the psychological, social and cultural aspects of involvement in science should be facilitated (Lacin-Simsek, 2009). With this aim in mind, in the reading text that was prepared titled "Joseph Priestley", at the first stage, the teacher candidates were presented with a text that focused on the scientist's life in the psychological, social and cultural dimensions. In this text, from a psychological perspective, the frame of mind that the scientist was in, and under which conditions he conducted his studies were explained. From the cultural aspect, the legacy he left to society with the studies he conducted and took part in during the period he lived in was emphasised; while in the social dimension, an attempt was made to throw light on the reflections of the studies he made in society and his relationships with other scientists. At the second stage, in the questions included, the extent to which the candidates accessed eight propositions that they could elicit from the text was examined, and also, four open-ended questions were included. With the questions asked in this part, the aim was for the candidates to develop their ability to understand both what they had read and the contextual aspect of science

\section{Analysis of Data}

The answers given by the teacher candidates to the questions they were asked in both reading texts were analysed. Percentage and frequency values were determined by grouping the answers as "correct, partially correct, incorrect and unanswered". The answer categories used in the analysis are shown below in Table 1. In order to ensure the reliability of the scoring, intrascorer reliability was calculated. Score-in reliability, the consistency of the points given by the same individual, is calculated and examined (Bikmaz-Bilgen \& Dogan, 2017). The intrascorer reliability coefficient for this study was found to be 0.92 .

Table 1. Answer categories used in analysis

\begin{tabular}{ll}
\hline Answer category & Explanation \\
\hline Correct & "Scientifically correct answer" \\
Incorrect & "Completely wrong answer" \\
Partially correct & "The answer is correct, but it is incomplete according to the exact answer" \\
Unanswered & "Blank answer" \\
\hline
\end{tabular}

\section{Findings}

The pre-service teachers who read the text titled "Van Helmont", which was prepared to explain the processual aspects of science, were required to answer the questions on the back page, and the answers they gave to the four questions were analysed and are shown in table 2.

Table 2. Analysis of answers given to questions for Van Helmont text

\begin{tabular}{lcccccccc}
\hline & Question 1 & \multicolumn{2}{c}{ Question 2 } & \multicolumn{2}{c}{ Question 3 } & \multicolumn{2}{c}{ Question 4 } \\
\hline Answ. categ. & f & \% & f & \% & f & \% & f & \% \\
\hline Correct & 31 & 46.97 & 65 & 98.49 & 39 & 59.09 & 52 & 78.79 \\
Incorrect & 33 & 50 & - & - & 6 & 9.09 & 14 & 21.21 \\
Partially corr. & - & - & - & - & 20 & 30.31 & - & - \\
Unanswered & 2 & 3.03 & 1 & 1.51 & 1 & 1.51 & - & - \\
Total & 66 & 100 & 66 & 100 & 66 & 100 & 66 & 100 \\
\hline
\end{tabular}

As it can be seen in Table 2, when the answers given to the first question, "What kind of hypothesis might Van Helmont have formed related to his studies?" were examined. It was revealed that $50 \%$ of the pre-service teachers gave incorrect answers. The only reason why the answers included in this category were accepted as incorrect was, in fact, that the candidates could not create a hypothesis statement. If we give examples: 
"He supposed that taking notes by observing and checking every moment would lead to correct information",

"By believing that plants were dependent on the soil, he judged that they were nourished by it, and he believed he had proved this with the decrease in soil mass in the experiment he performed".

Almost all the pre-service teachers gave correct answers to the second question, "How long did the scientist's studies take?". In the third question, the candidates were required to analyse the correct and incorrect deductions made by the scientist after they had read the relevant text, and it was determined that $59 \%$ of them made correct inferences. In this question, the reason why $30 \%$ of the candidates were judged to have given partially correct answers stemmed from the fact that they wrote only one of the correct and incorrect inferences correctly. Examining the fourth question, the preservice teachers were asked to evaluate the question, "Can we describe Van Helmont's experiment as successful or unsuccessful?" Considering that responses stated as "It would not be correct to say 'successful' or 'unsuccessful' ", "There are both correct and erroneous parts", "We have to consider it within the period when it was carried out", "It contributed to the development of science", and "They were pioneering studies" were accepted as correct. The fact that approximately $79 \%$ of the candidates gave correct answers is remarkable as a considerably high percentage.

The pre-service teachers who read the text titled "Joseph Priestley", which was prepared to explain the contextual aspects of science, were required to mark which of the propositions included on the back page were suitable for the text and to answer the questions. The analysis of the questions requiring marking is presented in Table 3.

Table 3. Analysis of responses given to questions requiring marking

\begin{tabular}{|c|c|c|c|}
\hline & $\mathbf{f}$ & $\%$ & Unmarked propositions \\
\hline 8 correct answers & 14 & 21.21 & - \\
\hline 7 correct answers & 25 & 37.87 & $\begin{array}{l}2 \text { candidates proposition \# } 1 \\
3 \text { candidates proposition \# } 3 \\
2 \text { candidates proposition \# } 4 \\
11 \text { candidates proposition \# } 5 \\
2 \text { candidates proposition \# } 6 \\
5 \text { candidates proposition \# } 8 \\
\end{array}$ \\
\hline 6 correct answers & 20 & 30.30 & $\begin{array}{l}3 \text { candidates proposition \# } 2 \\
6 \text { candidates proposition \# } 3 \\
4 \text { candidates proposition \# } 4 \\
12 \text { candidates proposition \# } 5 \\
6 \text { candidates proposition \# } 6 \\
2 \text { candidates proposition \# } 7 \\
7 \text { candidates proposition \# } 8\end{array}$ \\
\hline 5 correct answers & 5 & 7.57 & $\begin{array}{l}1 \text { candidate proposition \# } 2 \\
4 \text { candidates proposition \# } 3 \\
2 \text { candidates proposition \# } 4 \\
3 \text { candidates proposition \# } 5 \\
3 \text { candidates proposition \# } 6 \\
1 \text { candidate proposition \# } 7 \\
1 \text { candidate proposition \# } 8\end{array}$ \\
\hline 4 correct answers & 1 & 1.51 & 1 candidate propositions \# 2,3,5,6 \\
\hline 2 correct answers & 1 & 1.51 & 1 candidate propositions \# 1,2,3,4,6,8 \\
\hline
\end{tabular}

Examining Table 3, it is seen that after reading the Joseph Priestley text, the candidates were given fourteen separate propositions, and it was stressed that they should mark not the ones that were correct, but the ones that could be extracted from the text. In the analysis of the answers, it was determined that $21 \%$ of the candidates were able to make completely correct inferences (8), that about 38\% of them correctly indicated at most 7 propositions, and that 30\% of them correctly indicated 6 propositions. When the unmarked propositions were examined, it was determined that proposition number 5, "The views and beliefs that scientists possess influence their interpretation of their discoveries", could not be extracted by the highest percentage $(40.90 \%)$ of the candidates. This was followed by proposition number 3 , "Being subjected to violence due to their views do not change the opinions of scientists" at a rate of $22.72 \%$, proposition number 8 , "Scientists are people who devote a large part of their lives to scientific research and who put their names to different discoveries" at a rate of $21.21 \%$, and proposition number 6, "Incorrect interpretations by scientists do not always mean that the scientific knowledge they have discovered is useless" at a rate of $19.69 \%$, respectively, as propositions which could not be extracted by the candidates.

The analysis of the answers given to the four questions for the Joseph Priestley text is presented in table 4 . 
Table 4. Analysis of answers given to questions for Joseph Priestley text

\begin{tabular}{lcccccccc}
\hline & Question 1 & \multicolumn{4}{c}{ Question 2 } & \multicolumn{2}{c}{ Question 3 } & \multicolumn{2}{c}{ Question 4 } \\
\hline Answ. categ. & f & \% & f & \% & f & \% & f & \% \\
\hline Correct & 30 & 45.46 & 56 & 84.85 & 45 & 68.19 & 22 & 33.34 \\
Incorrect & 2 & 3.03 & 9 & 13.64 & 20 & 30.30 & 3 & 4.54 \\
Partially corr. & 32 & 48.48 & 1 & 1.51 & - & - & 40 & 60.61 \\
Unanswered & 2 & 3.03 & - & - & 1 & 1.51 & 1 & 1.51 \\
Total & 66 & 100 & 66 & 100 & 66 & 100 & 66 & 100 \\
\hline
\end{tabular}

Examining Table 4, the teacher candidates were asked to give answers to the first question, "Why is it important for scientists to publish their research?" according to the text that they had read. It is seen that the highest rate (48\%) was for partially correct answers. When the answers were examined, it was determined that instead of giving the answer that they should have extracted from the reading passage, the candidates wrote more general answers. For example, it was seen that they wrote sentences like "Publishing their research will be useful for mankind...". On the other hand, $45 \%$ of the candidates extracted the correct answer. In the second question, the pre-service teachers were asked "Although Priestley was the first person to discover oxygen, the eponym of this gas was Lavoisier. Explain why". It was determined that $85 \%$ of the candidates answered this question correctly. It was seen that $68 \%$ of the candidates gave the correct answer to the third question, "Do the dogmas and beliefs possessed by scientists have an impact on their research?". It is remarkable that almost $61 \%$ of the pre-service teachers gave only partially correct answers to the fourth question, "What are Priestley's other discoveries apart from oxygen?". When the answers were examined, it was seen that in $45 \%$ of the answers in the partially correct category, candidates wrote $\mathrm{CO}_{2}$ among Priestley's discoveries.

\section{Discussion and Conclusion}

When the data obtained in the study were evaluated, it was revealed that in the first question asked about the "Van Helmont" reading text, half of the pre-service teachers could not create a hypothesis statement. In the literature, hypothesis is defined as statements used in explaining an event or characteristic. In other words, when forming a hypothesis, a student puts forward a statement that is not completely developed and can be tested. At the hypothesisforming stage, rather than the explanations being correct, attention is given to making a hypothesis statement that conforms to scientific concepts and principles and reflects the causality of an event (Celik \& Ozbek, 2013). Forming a hypothesis in fact means making a specific type of prediction for a situation whose accuracy we can test with an experiment (Tan \& Temiz, 2003). Therefore, this prediction can be true or false, but if it is false, we can change our hypothesis. The fact that in this study, only $47 \%$ of the pre-service teachers were able to form a correct hypothesis means that their skills in this regard are in need of development. According to Harlen (1993), if we want children to be aware that scientific knowledge can be tested and can always be disproved, or it that can change in the light of further evidence, we have to enable them to acquire the skill of forming a hypothesis. Hypothesis forming, which is included among the experimental skills that are scientific process skills, is known to be among the skills that are difficult to acquire since it requires interpretation of abstract concepts. On the other hand, there are studies which support the idea that these skills can be developed with student-centred implementations. For example, the 7E model or the nature of science activities can help students to develop related skills (Can \& Pekmez, 2010; Celik \& Ozbek, 2013; Kanli \& Yagbasan, 2008).

The second question was of the kind that everyone who read the text carefully could answer immediately. Therefore, a very high correct answer rate of $98 \%$ was revealed. In reading comprehension, the reader compares his/her previous knowledge with what he/she learns from the text, synthesises it and reaches an opinion (Akyol, 2005). It is known that students who possess good reading skills as individuals are also successful in other subjects such as mathematics, science and geography (Bayat, Sekercioglu \& Bakir, 2014; Yilmaz, 2008). It is considered that since the response to this question includes a numerical value, it is easy to retain it in the memory.

In the third question, the correct and incorrect deductions that the scientist could make from his experiment were asked about, and a correct answer rate of 59\% was determined. Although this percentage is not very low, the rate of partially correct answers remained at around 30\%. Considering that the partially correct answers consisted of candidates' answers in which they gave only one of the deductions correctly, this may be evaluated as the fact that some students experienced some difficulty in interpreting statements that were not given explicitly in the text. Interpretation, means to grasp a writer's main idea by understanding his/her words and the views he/she puts forward, to comprehend the views that he/she does not express directly, and to define the scope of his/her thought (Yilmaz, 2008). In fact, interpretation means transporting knowledge to a higher level in a cognitive sense (Soylemez, 2016). Especially in their laboratory applications, it is considered that instead of explaining the steps of the experiment or activity they are to perform in a detailed way, providing pre-service teachers with environments where they themselves are involved in the process, where they can consider and plan, interpret and write, in short, where they encounter activities through which they can develop their skills, will contribute towards developing their ability to interpret what they have read (Kanli \& Yagbasan, 2008). 
In the fourth question, in which the candidates were asked to evaluate the scientist's research as successful or unsuccessful, 79\% of them gave the correct answer. Making an assessment is a high-level learning outcome. Moreover, it is one of the most important steps in critical thinking (Soylemez, 2016). Considered from this viewpoint, the high correct answer rate is considered to be a positive result in terms of reflecting the teacher candidates' critical thinking skills.

With this reading text presented to the pre-service teachers, an attempt was made to explain the processual aspect of science to the candidates via the subject of history of science (photosynthesis). In this way, the aim was for them to acquire an understanding of the scientific process. Their awareness of learning outcomes such as how Van Helmont defined a problem, how he formed a hypothesis, what he considered or did not consider when conducting research, how he gathered data, how he reached a conclusion, and the fact that he did not always reach a correct conclusion but that sometimes even this situation could contribute to science, made a contribution to achieving the aim of the study. Only with regard to the subject of hypothesis forming did the candidates' need of support come to the fore.

In the reading text prepared about Joseph Priestley, in the first part the teacher candidates were required to mark the propositions that were suitable for the text. Out of a total of fourteen propositions, eight were accepted as correct. Examining these propositions, the pre-service teachers were expected to extract these inferences from the text: scientists have inquisitive personality structures, science advances by adding new knowledge to the knowledge that existed before and by weeding out errors from it, exposure to violence because of their views does not change scientists' ideas, it is important for the research that is done to be published, the views and beliefs that scientists possess influence their interpretation of their research, scientists' incorrect interpretation of their findings does not always mean that those findings are useless, Priestley was an educator and writer as well as a scientist, and scientists devote a large part of their lives to scientific research and put their names to different discoveries. It was determined that a total of $21 \%$ of the candidates extracted all eight of the propositions, while a total of $68 \%$ of them elicited 6-7 propositions. Although this percentage is considerably high, it is striking that $41 \%$ of candidates within this group were not able to extract the proposition that "the views and beliefs that scientists possess influence their interpretation of their discoveries". In fact, it is stated in the text that since Priestley believed in Stahl's phlogiston theory, he named that gas that he isolated "dephlogisticated air". Because of this, although Priestley had isolated oxygen previously, the eponym for the gas became Lavoisier. The reason why some candidates could not elicit this proposition may be that they had difficulty in interpreting statements that were not stated explicitly. A similar situation was determined at a rate of $30 \%$ in the third question of the previous Van Helmont activity.

In the first question of the reading text about Joseph Priestley, the candidates were asked to state why it is important for scientists' research to be published. The most common answer category was determined to be partially correct answers at a rate of $48 \%$. Although it is emphasised in the text that despite the fact that Scheele conducted his research before Priestley, because he was late in publishing it, it was Priestley that went down in history as the first person to isolate oxygen. It was seen that the students gave general answers. It is thought that they may not have realised that they had to give an answer focusing on the text, that they might have been distracted, or that they might have behaved with the mentality of answering the questions and completing the task as quickly as possible. A high percentage of correct answers was determined for the second and third questions. The correct answers given to the questions about Lavoisier being the eponym for oxygen and about the dogmas and beliefs possessed by scientists are important in terms of reference to the contextual aspect of science.

The fact that in the first part of the activity about Priestley, candidates could not extract the proposition that "the views and beliefs that scientists possess influence their interpretation of their discoveries", yet that in the questions section, $68 \%$ of them were able to correctly answer the question "Do the dogmas and beliefs possessed by scientists have an impact on their research?" is thought to be due to the effect of the epistemological beliefs that they have. These beliefs are adopted with two basic approaches, namely the positivist and postmodern approaches. While the positivist approach is based on objectivity, in contrast to this approach which does not give the required value to subjectivity, in the postmodern approach, the importance of subjectivity in the creation and evaluation of knowledge is emphasised. At the same time, in the postmodern understanding of science, the subjective viewpoints of scientists have an effect on their observations (Terzi, 2005). It has already been determined that the candidates could not make an interpretation and extract the correct proposition from the text, but it can be understood that in this question they did in fact possess a postmodern belief. In the related literature, it is stressed that with student-centred approaches, a traditional positivist outlook can be transformed into a postmodern outlook (Yavuz, Buyukeksi \& Isik-Buyukeksi, 2014). However, there is still a need for broader and longer-term studies that can reveal this. It is striking that the majority of answers to the question included in the last part, "What are Priestley's other discoveries apart from oxygen?" were partially-correct answers. Although the statement that "Priestley discovered ten more gases in addition to the three (carbon dioxide, hydrogen and air) already known at that time" was included in the text, it is thought that the teacher candidates did not read the text carefully and so assumed that Priestley had discovered $\mathrm{CO}_{2}$. Reading comprehension means using previous knowledge to work out the ideas intended to be given in a text and assigning a meaning to these (Yilmaz, 2008). Considered from this viewpoint, it can be understood that the candidates were not able to effectively make the 
analysis expected of them. In the related literature, it is stated that students at university level need to have a high level of comprehension of what they read (Benzer, 2016).

With this reading text presented to the pre-service teachers, an attempt was made to explain the contextual aspect of science to the candidates via the subject of history of science (photosynthesis). Their awareness of learning outcomes such as what kind of personality structure Priestley had, how the psychological state of society during the years in which he conducted his research may have led people to react negatively to scientists, the fact that scientific research may last for many years and even the entire lifetime of a scientist, in scientific studies more than one person may work in the same field, sometimes they may contribute to each other's views, everything that scientists find may be a new discovery or a step on the road to a new discovery, sometimes the beliefs held by scientists can have an effect on the views they have regarding their research, and scientists are individuals who not only do their own research but are also useful to society, made a contribution to achieving the aim of the study. Only with regard to the matter of making more careful inferences from the text did the candidates' need of support come to the fore.

There is a need for teaching materials that include the conceptual, processual and contextual dimensions of science to be designed in different subjects at university level and for these to be presented to pre-service biology teachers in book format (Akcay, 2017). In this way, teacher candidates will have a command not only of the conceptual dimension of science, but also of its processual and contextual dimensions. In this sense, using a context-based learning approach, the contents prepared can be presented as worksheets or reading texts prepared with a history-focused approach. In this way, true-life situations selected from scientific implementations will have been conveyed to students. Since it is regarded as important for individuals who are to be teachers to possess a postmodern epistemological belief (Terzi, 2005), and the studies on the emergence of scientific information in the historical process will contribute to the development of the concept of "science culture" (Kandil-Ingec, Tekfidan \& Karagoz, 2016), it is recommended that longterm studies with larger samples inspired by the history of science or current topics are conducted. Pre-service teachers and teachers at work should be provided with courses to prepare course material for their students' needs. This can lead to the creation of original materials.

\section{References}

Ahopelto, I., Mikkila-Erdmann, M., Anto, E., \& Penttinen M. (2011). Future elementary school teachers' conceptual change concerning photosynthesis. Scandinavian Journal of Educational Research, 55(5), 503-515. doi: 10.1080/00313831.2010.550060

Akcay, S. (2017) Prospective elementary science teachers' understanding of photosynthesis and cellular respiration in the context of multiple biological levels as nested systems. Journal of Biological Education, 51(1), 52-65. doi:10.1080/00219266.2016.1170067

Akyol, H. (2005). Turkce ilkokuma yazma ogretimi [Turkish first reading and writing teaching]. Ankara, Turkey: Pegem A Publishing.

Appelget, J., Matthews, C. E., Hildreth, D. P., \& Daniel M. L. (2002). Teaching the history of science to students with Learning disabilities. Intervention in School and Clinic, 37(5), 298-303. doi: 10.1177/105345120203700506

Bahar, M. (2003). A study of pupils' ideas about the concept of life. Kastamonu Education Journal, 11(1), 93-104.

Bayat, N., Sekercioglu, G., \& Bakir, S. (2014). The relationship between reading comprehension and success in science. Education and Science, 39(176), 457-466.

Benzer, A. (2016). Turkce ve fen bilgisi ogretmen adaylarinin okudugunu anlama ve okuma stratejilerinin bazi degiskenler acisindan incelenmesi [The examination of reading strategies of science and Turkish teachers' reading comprehension and reading strategies in terms of some variables]. International Journal of Social Science, (43), 2130. doi: 10.9761/JASSS3209

Bikmaz-Bilgen, 0., \& Dogan, N. (2017). Puanlayicilar arasi guvenirlik belirleme tekniklerinin karsılastirilmasi [The Comparison of Interrater Reliability Estimating Techniques]. Journal of Measurement and Evaluation in Education and Psychology, 8(1), 63-78. doi: 10.21031/epod.294847

Campbell, N. A., Reece, J. B., Urry, L. A., Cain, M. L., Wasserman S. A., Winickoff, B., \& Jackson, R. B. (2010). Biology (8th ed.). San Francisco, CA: Pearson Benjamin Cummings.

Can, B., \& Pekmez, E. S. (2010). Bilimin dogasi etkinliklerinin ilkogretim yedinci sinif ogrencilerinin bilimsel surec becerilerinin gelistirilmesindeki etkisi [The effects of the nature of science activities on the development of seventh grade students' science process skillss]. Pamukkale University Journal of Education, (27), 113-123.

Crane, L., \& Winterbottom, M. (2008). Plants and photosynthesis: peer assessment to help students learn. Journal of Biological Education, 42(4), 150-156. doi:10.1080/00219266.2008.9656133 
Cakici, Y. (2009). Fen egitiminde bir onkosul: Bilimin dogasini anlama [A prerequisite in science education: Understanding nature of science]. Marmara University Ataturk Education Faculty Journal of Educational Sciences, (29), 57-74.

Celik, H., \& Ozbek, G. (2013). 7E ogretim modelinin hipotez kurma ve degisken belirleme becerileri uzerine etkisi [The effects of 7E instruction model on setting hypothesis and variable determination skills]. The Journal of the Industrial Arts Education Faculty of Gazi University, (31), 13-23.

Cohen, L., Manion, L., \& Morrison, K. (2007). Research methods in education. (6th ed.). London, UK: Routledge.

Collins, A., \& Spiegel, S. A. (2001). Teacher Research. Retrieved February 10, 2010, from http:/www.enc.org/professional/research/journal/science/documents.

Dogan, Y., \& Yilmaz, M. (2013). Yapilandirmaci programin ogrencileri fen ve teknoloji okuryazari yapma rolu ve programin uygulanmasina iliskin ogretmen goruslerinin incelenmesi [Examination of teachers' views about purpose of constructivist program makes students science and technology literacy]. Mustafa Kemal University Journal of Social Sciences Institute, 10(23), 119-129.

Driver, R., Leach, J., Millar, R., \& Scott, P., (1996). Young people's images of science. London, UK: Open University Press.

Ekiz, D. (2013). Bilimsel arastirma yontemleri [Scientific research methods]. Ankara, Turkey: Ani Publishing.

Gallagher, J. J. (1991). Prospective and practicing secondary school science teachers' knowledge and beliefs about the philosophy of science. Science Education, 75(1), 121-133.

Gonzalez-Rodriguez, C., Garcia-Barrios, S., \& Martinez-Lozada, C. (2009). Plant nutrition in Spanish secondary textbooks. Journal of Biological Education, 43(4), 152-158. doi: 10.1080/00219266.2009.9656175

Hall, D. O., \& Rao, K. K. (1994). Photosynthesis (5th ed.). Cambridge, UK: Cambridge University Press.

Harlen, W. (1993). Teaching and learning primary science (2nd ed.). London, UK: Paul Chapman Educational Publishing.

Henke, A., \& Hottecke, D. (2015). Physics teachers' challenges in using history and philosophy of science in teaching. Science \& Education, 24(4), 349-385.

Janssen, P.J.D., Lambreva, M.D., Plumere, N., Bartolucci, C., Antonacci, A., Buonasera, K., ... Rea, G. (2014). Photosynthesis at the forefront of a sustainable life. Frontiers in Chemistry, 2(36), 1-22. doi: 10.3389/fchem.2014.00036

Jensen, M. S., \& Finley F. N. (1995). Teaching evolution using arguments in a conceptual change strategy. Science Education, 79(2), 147-166.

Kandil- Ingec, S., Tekfidan, K., \& Karagoz, E. (2016). Fizik ders kitaplarinin bilim tarihi acisindan incelenmesi [Examination of physics textbooks in terms of history of science]. Fen Bilimleri Ogretimi Dergisi [Journal of Science Education], 4(2), 168-187.

Kanli, U., \& Yagbasan, R. (2008). 7E modeli merkezli laboratuvar yaklasiminin ogrencilerin bilimsel surec becerilerini gelistirmedeki yeterliligi [The efficacy of the 7e learning cycle model based on laboratory approach on development of students' science process skills]. Gazi University Journal of Educational Faculty, 28(1), 91-125.,

Keskin, H, Tezel, O., \& Acat, B. (2016). Ortaokul ogrencilerinin fen ve teknoloji dersine iliskin bilimsel okuryazarlik seviyeleri [Secondary students' level of scientific literacy related to science and technology course]. The Journal of Academic Social Science Studies, (47), 1-18.

Klopfer, L. E. (1969). The teaching of science and the history of science. Journal of Research in Science Teaching, 6(1), 8795.

Koch, A., \& Eckstein, S. G. (1995). Skills needed for reading comprehension of physics texts and their relation to problem-solving ability. Journal of Research in Science Teaching, 32(6), 613 - 628.

Kose, S. (2008). Diagnosing student misconceptions: using drawings as a research method. World Applied Sciences Journal, 3(2), 283-293.

Kose, S., \& Usak, M. (2006). Determination of prospective science teachers' misconceptions: photosynthesis and respiration in plants. International Journal of Environmental \& Science Education, 1(1), 25 - 52.

Lacin-Simsek, C. (2009). Fen ve teknoloji dersi ogretim programlari ve ders kitaplari bilim tarihinden ne kadar ve nasil yararlaniyor? [How much and how science and technology curriculums and textbooks benefits from history of science?]. Elementary Education Online, 8(1), 129-145.

Marques da Silva, J., Bernardes da Silva, A., \& Padua, M. (2007). Modulated chlorophyll a fluorescence: A tool for teaching photosynthesis. Journal of Biological Education, 41(4), 178-183.

Matthews, M. R. (1994). Science teaching: the role of history and philosophy of science. Abingdon, RN: Routledge. 
Matthews, M. R. (2009). Science and worldviews in the classroom: Joseph Priestley and photosynthesis. In M.R. Matthews (Ed.), Science, worldviews and education (pp.271-302). Dordrecht, The Netherlands: Springer.

McComas, W.F., Clough, M.P., \& Almazroa, H. (2002). The role and character of the nature of science in science education. In W. F. McComas (Ed.), The nature of science in science education: Rationales and strategies (pp.3-39). Norwell, MA: Kluwer Academic Publishers.

Melis, A., \& Happe, T. (2004). Trails of green algae hydrogen research- from Hans Gaffron to new frontiers. Photosynthesis Research, 80(1-3), 401-409.

Metioui, A., Matoussi, F., \& Trudel, L. (2016). The teaching of photosynthesis in secondary school: A history of the science approach. Journal of Biological Education, 50(3), 275-289.

Mikkila-Erdmann, M. (2001). Improving conceptual change concerning photosynthesis through text design. Learning and Instruction, 11(3), 241-257. doi: 10.1016/S0959-4752(00)00041-4

MEB (Milli Egitim Bakanligi) [Ministry of Education], (2013). Biyoloji Dersi (9, 10, 11 ve 12. Siniflar) Ogretim Programi [Secondary School Biology Curriculum (Grades 9-12)]. Retrieved January 8, 2016, from. http://ttkb.meb.gov.tr/program2.aspx

Morgil, I., Temel, S., Gungor-Seyhan, H., \& Ural-Alsan, E. (2009). Proje tabanli laboratuar uygulamasinin ogretmen adaylarinin bilimin dogasi konusundaki bilgilerine etkisi [The effect of project-based laboratory practice on the knowledge of teacher candidates about the nature of science]. Journal of Turkish Science Education, 6(2), 92-109.

Narguizian, P. J. (2002). The history of science in secondary biology textbooks in the United States: A content analysis (Unpublished doctoral thesis). University of Southern California, California, USA.

Ozay, E., \& Oztas, H. (2003). Secondary students' interpretations of photosynthesis and plant nutrition. Journal of Biological Education, 37(2), 68-70.

Patric, P., \& Matteson, S. (2018). Elementary and middle level biology topics: a content analysis of science and children and science scope from 1990 to 2014. Journal of Biological Education, 52(2), 174-183. doi: 10.1080/00219266.2017.1293556

Raven, P. H., Johnson, G. B., Mason, K. A., Losos, J., \& Singer, S. (2011). Biology (9th ed.). New York, NY: The MacGraw-Hill Companies.

Ross P., Tronson, D., \& Ritchie, R. J. (2006). Modelling photosynthesis to increase conceptual understanding. Journal of Biological Education, 40(2), 84-88. doi: 10.1080/00219266.2006.9656019

Saka, A. (2019). Development of preservice biology teachers' skills in the causal process concerning photosynthesis. Journal of Education and Training Studies, 7(4), 51-62. doi: 10.11114/jets.v7i4.4022

Schattner, P. (2015) The case for 'story-driven' biology education. Journal of Biological Education, 49(3), 334-337. doi: $10.1080 / 00219266.2015 .1058844$

Soylemez, Y. (2016). Icerik analizi: Elestirel dusunme [Content analysis: Critical thinking]. EKEV Akademi Dergisi [EKEV Academy Journal], 20(66), 671-696.

Svandova, K. (2014). Secondary school students' misconceptions about photosynthesis and plant respiration: Preliminary results. Eurasia Journal of Mathematics, Science and Technology Education, 10(1), 59-67. doi: 10.12973/eurasia.2014.1018a

Tan, M., \& Temiz, B. K. (2003). Fen ogretiminde bilimsel surec becerilerinin yeri ve onemi [The importance and role of the science process skills in science teaching]. Pamukkale University Journal of Education, (13), 89-101.

Tasar, M. F. (2003). Teaching history and the nature of science in science teacher education programs. Pamukkale University Journal of Education, (13), 30-42.

Tekkaya, C., Capa, Y., \& Yilmaz, O. (2000). Biyoloji ogretmen adaylarinin genel biyoloji konularindaki kavram yanilgilari [Biology teacher candidates' misconceptions about general biology]. Hacettepe University Journal of Education, (18), 140-147.

Terzi, A. R., (2005). Universite ogrencilerinin bilimsel epistemolojik inanclari uzerine bir arastirma [A research on the scientific epistemological beliefs of university students]. Afyon Kocatepe University Journal of Social Sciences, 7(2). 315-330.

Tunc-Sahin, C., \& Say, O. (2010). Ilkogretim ogrencilerinin bilimsel okuryazarlik duzeylerinin incelenmesi [Investigation of scientific literacy levels of elementary students]. ZKU Journal of Social Sciences, 6(11), 223-240.

Vartak, R. (2006). Photosynthesis in plants with non-green leaves. Journal of Biological Education, 40(4), 178-180. doi: 10.1080/00219266.2006.9656041. 
Wandersee, J. H. (1985). Can the history of science help science educators anticipate students'misconceptions? Journal of Research in Science Teaching, 23(7), 581-597.

Wang, H. (1998). Science in historical perspectives: a content analysis of the history of science in secondary school physics education (Unpublished doctoral thesis). University of Southern California, California, USA.

Yavuz, S., Buyukeksi, C., \& Isik-Buyukeksi, S. (2014). Effect of science fair on epistemological beliefs. Karaelmas Journal of Educational Sciences, 2, 168-174.

Yenilmez, A., \& Tekkaya, C. (2006). Enhancing students' understanding of photosynthesis and respiration in plant through conceptual change approach. Journal of Science Education and Technology, 15(1), 81-87.

Yilmaz, M. (2008). Turkcede okudugunu anlama becerilerini gelistirme yollari [The developing methods of reading comprehension skills in Turkish]. Mustafa Kemal Journal of University Social Sciences Institute, 5(9), 131-139. 
Appendix 1. Reading texts about Van Helmont

\section{VAN HELMONT}

The famous Greek philosopher and naturalist Aristotle (384-322 B.C.) believed that plants obtained their nutrients from the soil. In studies conducted today, it is concluded that even after all the centuries that have elapsed between the time of Aristotle and the present day, students at different levels still have such ideas. In the 17th century, the Flemish scientist Van Helmont conducted the first studies related to the synthesis of plant material (1642). He observed his research patiently, which lasted for five years, and made measurements. Helmont weighed out a total of $90 \mathrm{~kg}$ of soil and sowed a 2.5-kg willow sapling in it. For five years, he watered the soil with only rainwater and distilled water, and also weighed the leaves that fell from the tree. At the end of the experiment, the tree weighed $77 \mathrm{~kg}$, while the soil had lost only 57 grams. Van Helmont completed his experiment and concluded that the 74.5-kg mass gained by the tree had come from the water added. In other words, he believed that the water had been converted into vegetable matter.

In terms of method, this experiment by Van Helmont was correct. However, we cannot say that it was correct with regard to the conclusion. Science has witnessed innumerable experiments like this, beginning with a correct method and ending with an incorrect inference based on the scientist's opinion, intentions, world view and desires. Nevertheless, this misconception by Van Helmont resulted not only from his fixed ideas but also from his ignorance of photosynthesis. Photosynthesis is a reaction which enables plants, by extracting carbon dioxide from the atmosphere and water from the soil, to store up carbon and oxygen within themselves in the form of carbohydrates and also to release an amount of oxygen back into the atmosphere. In this way, they both meet their own nutritional needs and allow oxygen-breathing creatures to breathe the oxygen they give back to the atmosphere. The water mass of a newlycut tree is about two-thirds of its total mass. In this sense, Van Helmont is partially correct. However, while $90 \%$ of the mass of a newly-cut tree consists of carbon and oxygen originating from photosynthesis, the remaining part is made up of hydrogen taken from water and nitrogen taken from the soil and other trace elem ents (about 1\% in total). Although Van Helmont indicated the 57 -gram soil loss as due to this $1 \%$ nitrogen loss, he was overcome by personal ideas here and believed this to be due to a measurement error.

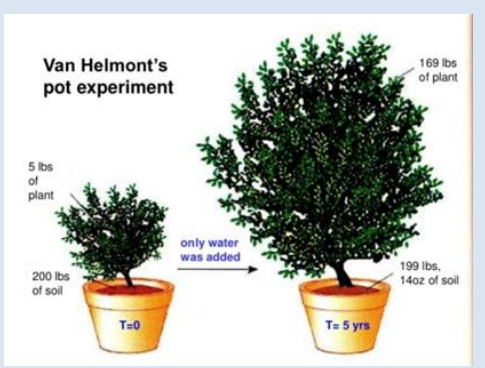

Questions about text:

1. What hypothesis did Van Helmont have in his experiment?

2. How long did Van Helmont's observations and measurements last?

3. According to Van Helmont's experiment results, what are the true and false inferences that he found?

True inference: False inference:

4. Can we describe the Van Helmont experiment as successful or unsuccessful? Explain why 
Appendix 2. Reading text about Joseph Priestley

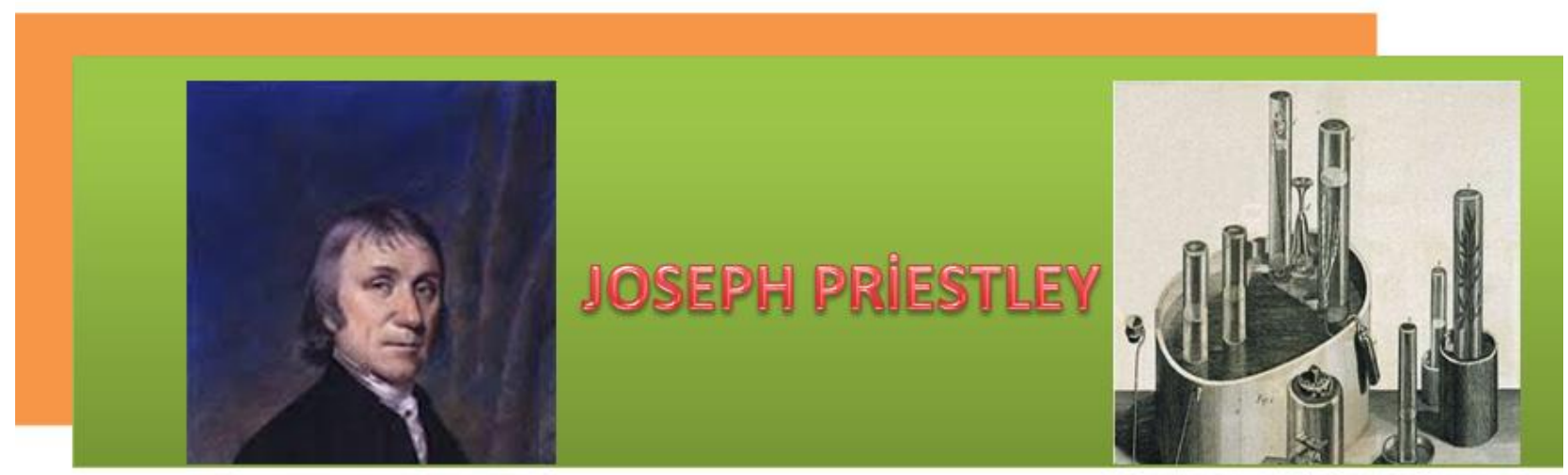

(Psychological aspect): Joseph Priestley experienced the French and American Revolutions and received training as a priest. Due to his religious views he later became a dissident priest in Yorkshire. Like Michael Faraday, Priestley also had religious views that were against those of the Anglican Church. Although he was a pious man, he questioned many of the doctrines of Christianity. With the publication of his book, "A History of the Corruptions of Christianity" in 1782, he became known as a man who was against the basic beliefs of Christianity. Priestley began to be regarded as a problem by the Anglican Church and supporters of the King. In 1792, an angry mob made up of Priestley's enemies destroyed his house, library, laboratory and chapel. Priestley moved to London, but his enemies did not stop following him there. Finally, in 17934, he emigrated to the USA; there, he was respected as a scientist and intellectual.

(Cultural aspect): Priestley was born in Yorkshire, England. While working as a science teacher, his interest in chemistry increasingly grew. In 1758, he opened a day school and achieved great success in science education by providing his students with the opportunity to use the most advanced scientific processes of the day. Between the years 1763 and 1768, he attended conferences related to chemistry and meetings at which his experiments were given practical demonstrations. After meeting the American scientist, diplomat and inventor, Benjamin Franklin (17061790), in London, his interest in science grew even more. In 1767, Priestley returned to Yorkshire as a priest of the church. He lived very close to a brewery and he would go there and collect the gas that emerged from the barrels during fermentation, that is, the "air". He noticed that this gas, which we know today by its name of carbon dioxide $\left(\mathrm{CO}_{2}\right)$, $\mathrm{Could}$ be dissolved in water and produce an effervescent, pleasant-tasting drink. Thus, he discovered soda. Priestley also discovered ten more gases in addition to the three (carbon dioxide, hydrogen and air) already known at that time. One of these, nitrous oxide $\left(\mathrm{N}_{2} 0\right.$, or laughing gas) later became one of the first anaesthetics used in operations. Two years after discovering nitrous oxide, Priestley also isolated oxygen.

(Social aspect): Oxygen was discovered by two different chemists independently of each other:Joseph Priestley (17331804) from Britain and Carl Wilhelm Scheele (1742-1786) from Sweden. Scheele made his discovery in 1772 but did not publish his research until 1777; Priestley, however, made his discovery in 1774 and published his findings in 1775. Therefore, in the beginning, the honour of discovering oxygen belonged only to Priestley. In the experiments he carried out, Priestley observed that a colourless gas was dispersed, and that a candle held close to this gas burned more brightly. At first, he supposed that this gas was nitrogen monoxide, which he had discovered before and named "nitrous air". Alerted by Antoine Lavoisier, he understood that it was a new gas which accelerated combustion. Priestley was the first person to discover oxygen, but when describing this gas, he gave an inaccurate explanation. Because he believed in the phlogiston theory put forward by Stahl, he named the oxygen gas he had discovered "dephlogisticated air". The person who revealed that this gas was oxygen gas, who gave this name to the gas and who revolutionised chemistry by demolishing the phlogiston theory was Lavoisier. Lavoisier correctly evaluated the discoveries of Scheele and Priestley who worked in this field and revealed that oxygen was an element and that it was found in the composition of the atmosphere. 
Select the results that can be reached by taking into consideration the texts you read above, by choosing from the following proposition items $\sqrt{ }$ mark the appropriate ones (Caution: not the correct ones, please indicate the results that you can read)

(.....) Scientists have a questioning personality structure

(.....) Science proceeds in the form of adding new ones to the previous information and removing the errors.

(.....) Sometimes scientific discoveries are the result of very long-term studies and sometimes with very short-term studies for example Newton's finding gravity from the apple falling from the tree.

(.....) Violations of their opinions did not change the thoughts of scientists

(.....)Today, scientific discovery is difficult, because many things have already been found. (.....) It is important to publish the studies

(.....)His/her views and beliefs have influenced scientists in interpreting their discoveries (.....) Scientists are very intelligent and highly skilled. They're different from normal people. (.....) Scientists are often impatient, introverted and abstract people from society

(.....) Scientists' misinterpretations do not necessarily mean that the scientific knowledge they find is useless.

(.....) A good scientist always prioritizes the ideas of society.

(.....) Priestley was an educator, pastor and also a scientist.

(.....) Scientific studies are intensive work, long-term studies and scientific processes.

(.....) Scientists are people who divide a large part of their lives into scientific studies and sign different discoveries.

Questions about text:

1. Explain why it is important for scientists to publish their work?

2. Although Priestley was known as the first person to discover oxygen, it's name father was Lavoisier. Describe why?

3. Do the dogmas and beliefs of scientists affect their work? Please explain.

4. What are the discoveries of Priestley other than oxygen? 